\title{
Trace Elements in Coal Ash
}

\section{Overview}

According to the U.S. Energy Information Association (EIA), approximately 37 percent of the electricity currently produced in the United States is generated using coal (U.S. Energy Information Administration, 2013). Coal ash (also known as coal combustion products) includes bottom ash, fly ash, and flue gas desulfurization products (fig. 1), which are generated in amounts averaging 130 million tons per year. In 2013, 14.5 million tons of bottom ash, 53.4 million tons of fly ash, and 35.1 million tons of flue gas desulfurization products were produced (American Coal Ash Association, 2013). The EIA predicts that coal use and coal ash generation in the United States will remain at current levels over the next few decades (U.S. Energy Information Administration, 2013).

Coal fly ash consists of fine particles, which contain a mixture of minerals such as clays, quartz, iron oxides, aluminosilicate glass formed by melting of mineral matter at the high temperatures of combustion, and unburned carbon remaining after the combustion process. Major chemical constituents of coal fly ash typically include silicon ( $\mathrm{Si}$ ), aluminum (Al), and iron $(\mathrm{Fe})$, listed in order of decreasing abundance when expressed as oxides (elements in combination with oxygen), with lesser amounts of oxides of calcium (Ca), magnesium $(\mathrm{Mg})$, potassium $(\mathrm{K})$, sulfur $(\mathrm{S})$, titanium $(\mathrm{Ti})$, and phosphorus $(\mathrm{P})$ whose proportions tend to be more variable. Coal ash also contains minor amounts of trace elements, including chromium (Cr), nickel (Ni), zinc ( $\mathrm{Zn})$, arsenic (As), selenium (Se), cadmium (Cd), antimony $(\mathrm{Sb})$, mercury $(\mathrm{Hg})$, and lead $(\mathrm{Pb})$. In addition, uranium (U) is commonly present at concentrations ranging from 10 to $30 \mathrm{ppm}$, which is near the upper limit of concentrations found in naturally formed rocks such as granite and black shale (Zielinski and others, 2007).

In the United States, coal ash is currently disposed of in ash impoundments or landfills (fig. 2). Storage or disposal of large volumes of coal ash in suitably engineered and monitored impoundments or landfills is costly and may be limited by near-site storage capacities. Long-term storage of coal ash can be problematic because water infiltration (from rain or snow) combined

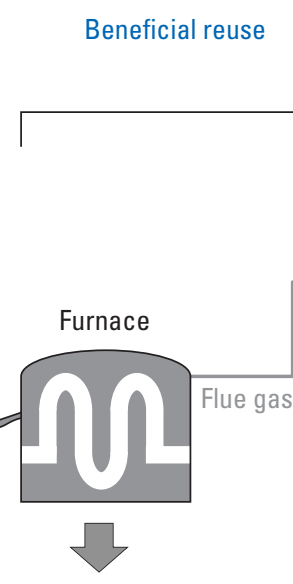

Bottom ash combusted in one or more furnaces, and part of the coal ash present (bottom ash) falls to the bottom of the furnace.
Coal is first

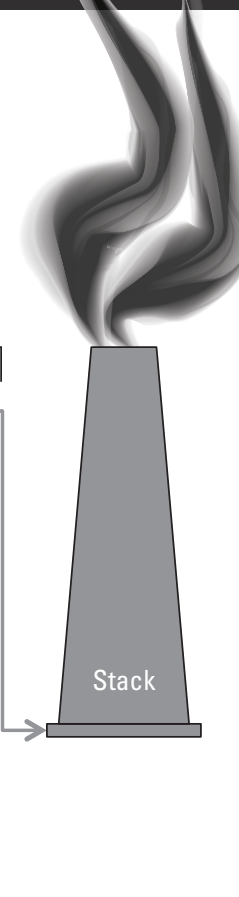

desulfurization products

Following this, flue gas desulfurization systems (scrubbers), if present, remove sulfur dioxide and other unwanted vapors from the flue gas, and capture them as solid flue gas desulfurization products.
The remaining flue gas and a very small fraction of the particulates not captured by these emission control devices are emitted from the stack.
Figure 1. The main processes involved in coal combustion and generation of coal ash (bottom ash, fly ash, and flue gas desulfurization products) at a coal-fired powerplant. The coal ash generated as a result of coal combustion is collected and stored or reused for beneficial purposes.

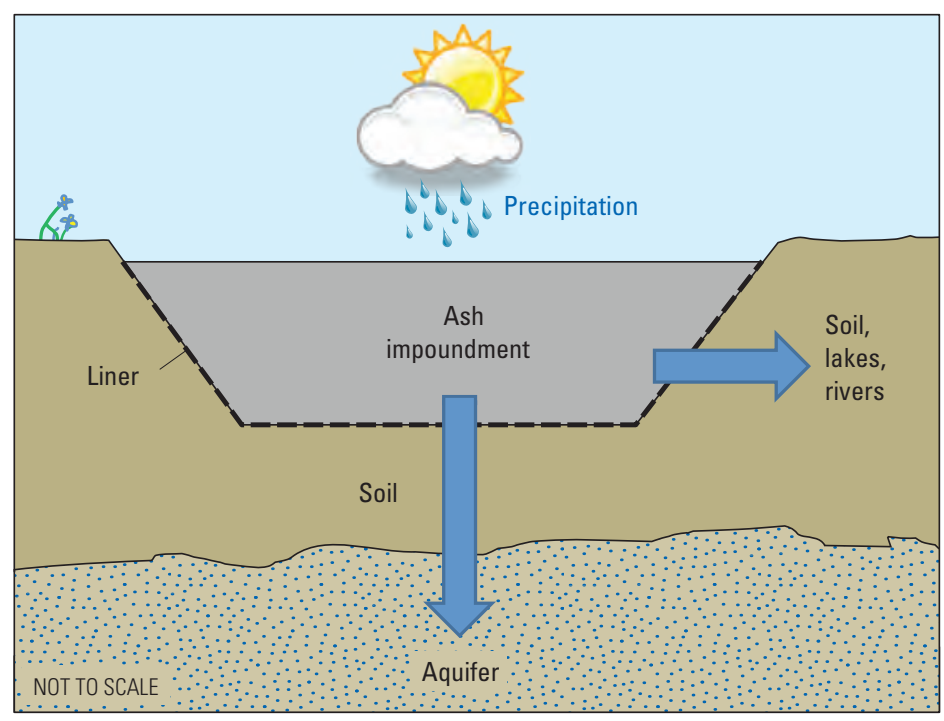

Figure 2. Potential pathways by which coal ash and its elemental constituents can escape from ash impoundments. Precipitation (rain and snow) can lead to water infiltration through the ash into groundwater aquifers, soil, lakes, and rivers. The liner helps prevent migration of constituents from the impoundment to its surroundings. 
with leaky storage sites may result in the transport of coal ash and its constituent elements into the local environment. If ash impoundments fail, there is potential for widespread and prolonged impacts such as impairment of ecosystem functions and the loss of plant and animal life and habitat. Recent examples of ash releases include the Tennessee Valley Authority Kingston, Tennessee, coal ash spill in December 2008, which released approximately 5.4 million cubic yards of ash into the Emory and Clinch Rivers in Tennessee (U.S. Environmental Protection Agency, 2012a), and the Eden, North Carolina, spill in February 2014, which released up to 39,000 tons of coal ash into the Dan River in North Carolina (U.S. Environmental Protection Agency, 2015a). Additionally, a number of other ash impoundments across the United States have been identified by the U.S. Environmental Protection Agency (EPA) as having the potential for significant hazardous impacts in the event of an ash spill (U.S. Environmental Protection Agency, 2014a).

An alternative to ash storage and disposal is ash utilization, primarily as an additive to concrete or other modern construction materials, and secondarily as structural and embankment fill. The American Coal Ash Association estimates that approximately 43 percent of the coal ash currently produced is beneficially reused (American Coal Ash Association, 2013).

\section{Trace Elements in Coal Ash}

Many trace elements such as chromium, arsenic, and mercury can be toxic to humans and ecosystem functioning at relatively low concentrations, and for these reasons, state and federal institutions monitor and regulate the concentrations of many trace elements in rivers and lakes, which provide sources of drinking water to towns and cities (U.S. Environmental Protection Agency, 2014b).

Trace elements are present in coal ash because the parent coal from which the ash is derived also contains trace elements as a result of natural formation processes. During combustion, most trace elements in the parent coal are retained in the residual coal ash and are concentrated in the smaller volume of the ash compared to the original coal. Trace element concentrations in coal ash are therefore higher compared to the parent coal (Carlson and Adriano, 1993; Meij, 1994; Jankowski and others, 2006). Trace elements in coal ash are typically present at partper-million ( $\mathrm{ppm}$ ) to part-per-billion ( $\mathrm{ppb}$ ) levels, and vary due to differences in the composition of the parent coal, combustion processes, and ash collection methods at powerplants.

Due to the trace element content in coal ash, there is interest in assessing (1) the properties and behavior of coal ash and its constituent trace elements in various environments, (2) the potential for human exposure, and (3) the potential for extracting elements of interest for reuse in various industries. For example, a recent study of runoff water from coal ash-amended concrete demonstrated that trace element dissolution from the concrete to the water was low (Cheng and others, 2008). Another concern is the emission of the radioactive element radon ( $\mathrm{Rn})$ from coal ash-amended construction materials. Studies have shown that the emission of radon from construction materials depends on many factors, such as the composition of the material and the manufacturing process, and is generally much lower than radon emissions from common rocks and soils (Kovler and others, 2005; Zielinski and others, 2007).
Other studies have examined the impact of coal ash on natural ecosystems. A study of the Tennessee Valley Authority Kingston coal ash spill in 2008 found that river-water trace element concentrations were not elevated in areas impacted by the ash spill due to dilution (Ruhl and others, 2009) but river sediments contained elevated levels of arsenic and mercury (Ruhl and others, 2010; Deonarine and others, 2013). A further study by Ruhl and others (2012) examined the impact of discharges from coal-fired powerplants and coal ash treatment ponds into North Carolina lakes and found that arsenic, nickel, antimony, and selenium levels in water and sediments were elevated compared to EPA water quality standards (Ruhl and others, 2012).

\section{USGS Coal Ash Research}

The U.S. Geological Survey (USGS) has conducted studies in which bulk chemical and mineralogical analyses, electron microscope observations, laboratory leaching experiments, and various micro-analytical techniques were utilized to (1) examine the properties of trace elements in coal fly ash, and (2) investigate the behavior of these trace element constituents under different environmental conditions.

\section{Trace Elements in Coal Fly Ash: Speciation and Occurrence}

Coal fly ash samples were examined to determine which trace elements were present, their concentrations, and chemical speciation. The chemical speciation of a trace element refers to its chemical and physical form in the coal ash, for example, whether it occurs as a solid, liquid, or gaseous phase, its oxidation state, and chemical bonds with other elements. Chemical speciation is an important factor which influences the properties of trace elements and their behavior in various environments.

Coal fly ash samples (designated here as fly ash samples A, B, and C) were collected from three U.S. coal-fired powerplants. One plant produces coal fly ash (fly ash C) from low-sulfur coal mined in the Powder River Basin of Wyoming and Montana (see map below), whereas the other two plants produce coal fly ash (fly ashes A and B) from coal mined in the Appalachian Basin having high and relatively low sulfur contents, respectively. Fly ash $\mathrm{C}$ contained lower concentrations of most measured trace elements compared to fly ashes A and B (fig. 3). Also, the two Appalachian Basin fly ashes had different trace element compositions, especially for arsenic.

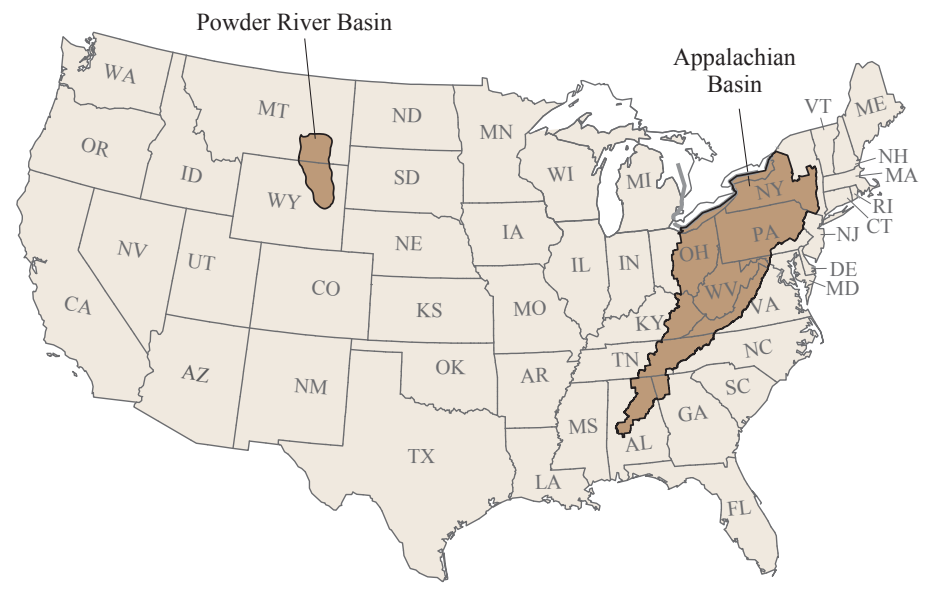


Electron microscopy techniques were used to examine fly ash structure and elemental composition. Transmission electron microscopy images of fly ash A show that there are two components of fly ash: glassy spheres and surface coating (fig. $4 A$ ). A higher resolution image of the fly ash surface coating (fig. $4 B$ ) indicated that it consists of fine nanometer-sized structures which lack crystalline form and consist largely of carbon. Electron microscopy coupled with compositional mapping indicated that trace elements such as vanadium (V), zinc, molybdenum (Mo), thallium $(\mathrm{Tl})$, and lead are associated with the surface coating of fly ash A.

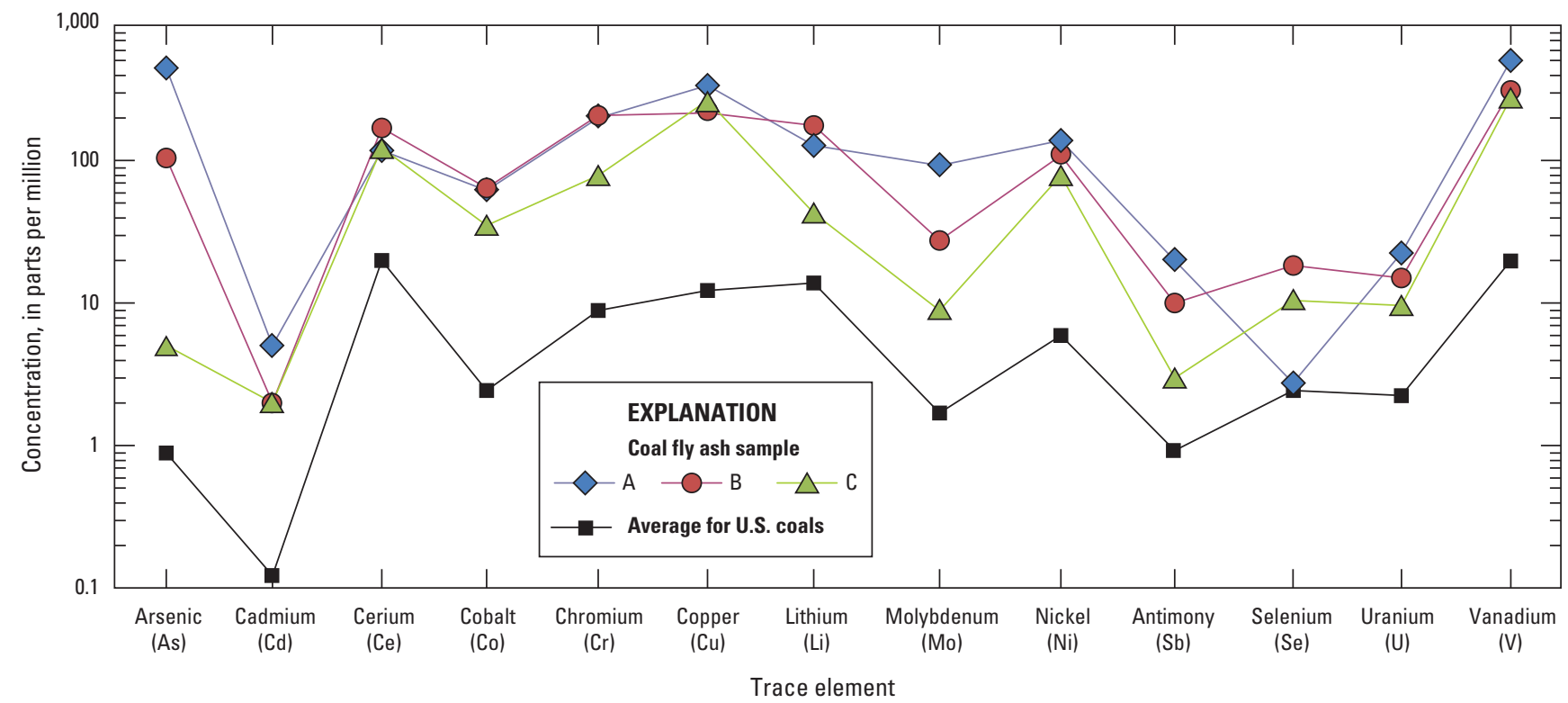

Figure 3. Concentrations of selected trace elements in three coal fly ash samples from the Appalachian Basin (A and $B)$ and the Powder River Basin of Wyoming (C), compared to average trace element concentrations in U.S. coals (Bragg and others, 1998).
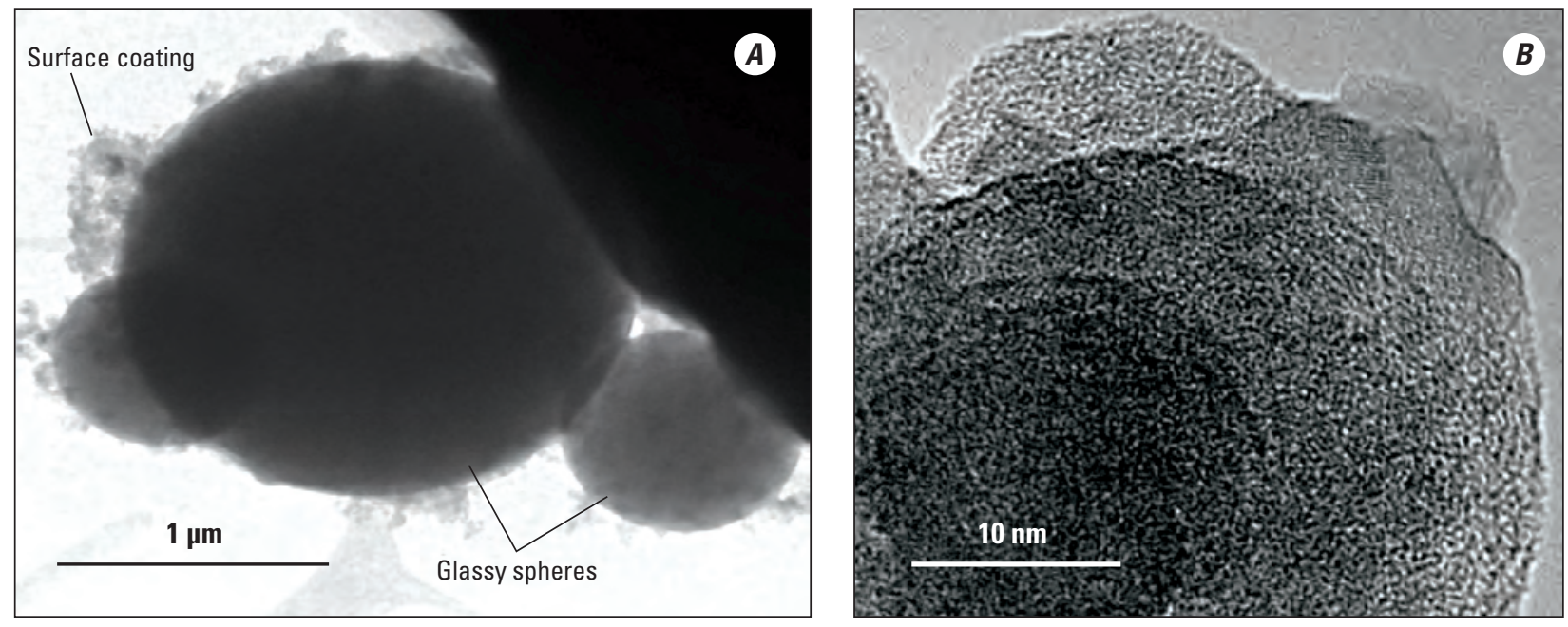

Figure 4. Electron microscopy images of fly ash. $A$, Two components of fly ash: glassy spheres and fine-grained surface coating. $B$, Higher resolution image of the surface coating, showing regions lacking crystalline form. Images were obtained at the Virginia Polytechnic Institute and State University Nanoscale Characterization and Fabrication Laboratory. 1 micrometer ( $\mu \mathrm{m})$ equals $1 / 1,000$ of a millimeter; 1 nanometer $(\mathrm{nm})$ equals 1/1,000,000 of a millimeter. 
High-energy X-rays from a synchrotron radiation source were also utilized to study the chemical speciation of trace elements present in the fly ash samples. These techniques identified regions enriched in elements such as arsenic (fig. $5 \mathrm{~A}$ ) and its oxidation state. Using this approach, the X-ray absorption spectrum of fly ash A indicated that most of the arsenic (89\%) was present as the more oxidized $\mathrm{As}^{5+}$, whereas only a small fraction (11\%) was present as $\mathrm{As}^{3+}$ (fig. 5B). These two forms of arsenic are the most common in aquatic environmental systems such as rivers and lakes and also exhibit different properties. For example, $\mathrm{As}^{3+}$ is considered to be more toxic than $\mathrm{As}^{5+}$ (Smedley and Kinniburgh, 2001).

Similarly, chromium in fly ash A was present as two different chemical forms: $\mathrm{Cr}^{3+}$ and a very low percentage of $\mathrm{Cr}^{6+}$ (spectrum not shown). $\mathrm{Cr}^{6+}$ compounds readily dissolve in water while $\mathrm{Cr}^{3+}$ compounds do not (U.S. Environmental Protection Agency, 2013a). Both chromium species are found in aquatic environments. $\mathrm{Cr}^{3+}$ is a nutritionally essential element in humans while $\mathrm{Cr}^{6+}$ is a carcinogen (U.S. Environmental Protection Agency, 2013b).

\section{Behavior of Coal Fly Ash and Its Trace Element Constituents Under Different Environmental Conditions}

A set of laboratory experiments was conducted to investigate how different redox conditions (oxic and anoxic) affect the dissolution or leaching of trace elements from coal fly ash into simulated freshwater. Both oxygen-rich (oxic) and oxygen-poor (anoxic) regions can be found in natural ecosystems. Oxic regions are typically found in the surface waters of rivers and lakes while anoxic regions are commonly found in bottom waters and sediments. Redox condition is an important factor in environmental systems because it influences the chemical speciation and behavior of trace elements.

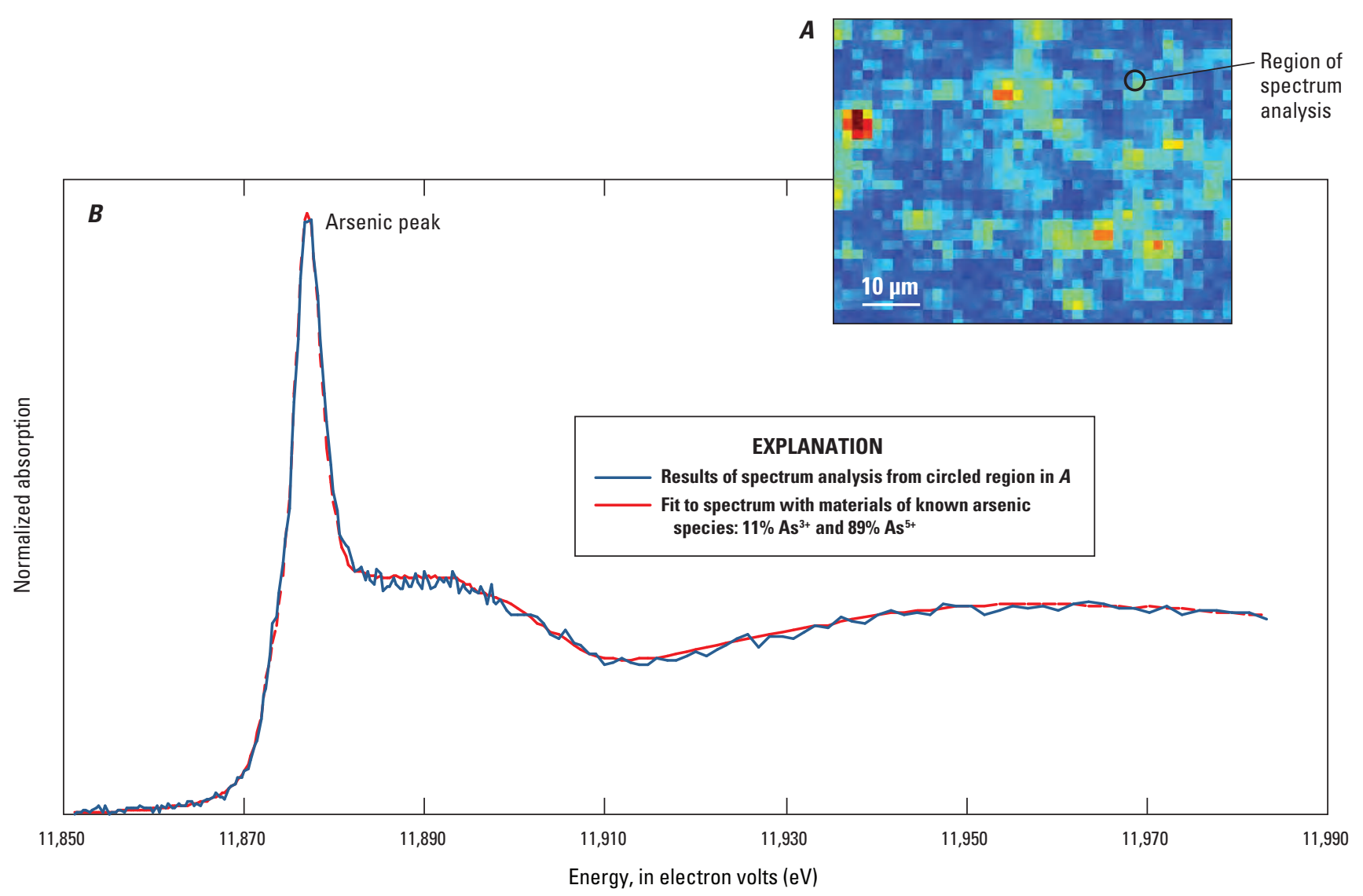

Figure 5. A, Arsenic (As) elemental map of fly ash sample A showing relative concentrations; the relative highest concentrations of arsenic are shown in red and lowest concentrations are shown in blue. $B, X$-ray absorption spectrum of the region of analysis circled in $A$, and fit to spectrum with materials of known arsenic species, which demonstrates that two chemical forms of arsenic, $\mathrm{As}^{3+}$ and $\mathrm{As}^{5+}$, are present. Synchrotron analyses were performed at beam line 2-3 at the Stanford Synchrotron Radiation Lightsource in Menlo Park, California. 
In these experiments, small volumes of oxic and anoxic freshwater without measurable arsenic and chromium were exposed to fly ashes A and B, and dissolved arsenic and chromium concentrations in the freshwater were measured over time (fig. 6). The results of the experiments showed that arsenic dissolved from fly ashes A and B into the freshwater under both oxic and anoxic conditions (fig. 6A). Dissolved arsenic concentrations increased over time, and maximum concentrations at the end of the 28-day (672-hour) experiment ranged from 30 to $150 \mathrm{ppb}$, and were above the EPA Maximum Contaminant Level (MCL) of $10 \mathrm{ppb}$ for total arsenic in drinking water (U.S. Environmental Protection Agency, 2014b). Arsenic is a trace element of concern because exposure can lead to skin damage, circulatory system problems, and an increased risk of cancer in humans (Eckley and Branfireun, 2008).

In contrast to arsenic, chromium dissolved only from fly ash $\mathrm{A}$ in oxic freshwater, and little or no chromium dissolved from fly ash B in oxic or anoxic freshwater (fig. 6B). In these cases, chromium was most likely present as an insoluble species and did not dissolve under the conditions tested (Guertin and others, 2004). During the timeframe of the experiment, dissolved chromium concentrations in freshwater were below the EPA MCL of $100 \mathrm{ppb}$ for total chromium in drinking water (U.S. Environmental Protection Agency, 2013b). Chromium is a trace element of concern because concentrations in drinking water above the MCL can be toxic (U.S. Environmental Protection Agency, 2013b).

Overall, the data obtained from these experiments improve our understanding of the structure of fly ash particles and their trace element content, as well as the leaching behavior of trace elements in coal ash, such as arsenic and chromium, under environmental conditions typically found in rivers and lakes.

\section{A. Total arsenic}

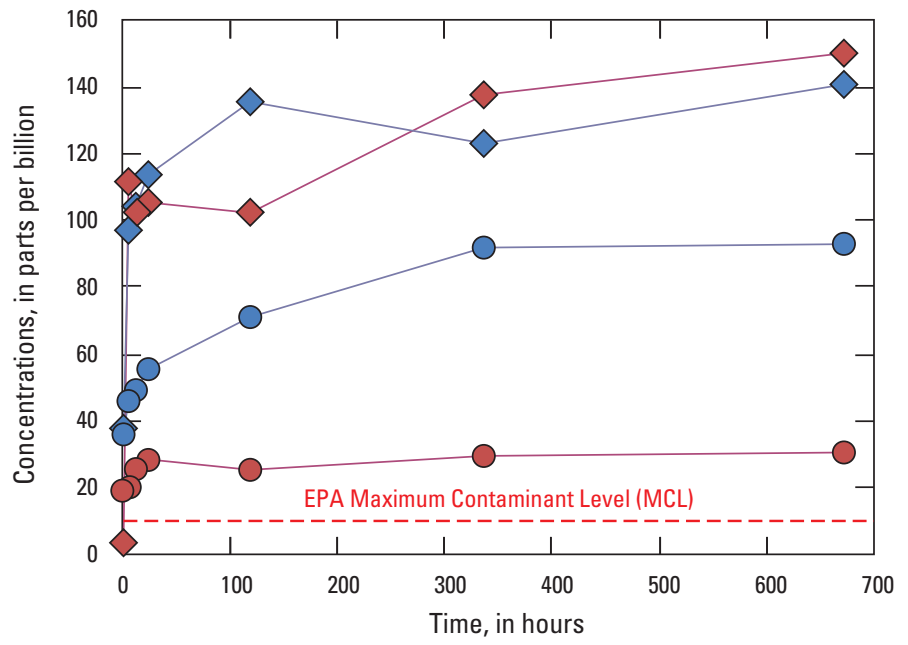

Figure 6. Results of dissolution experiments with fly ashes $A$ and $B$ in simulated oxic and anoxic freshwater at $\mathrm{pH} 7$. $A$, For arsenic experiments, arsenic dissolved from fly ashes $A$ and $B$ under both oxic and anoxic conditions, and increased over the course of the 28-day (672-hour) experiment. $B$, For chromium experiments: for fly ash $A$, under oxic conditions, dissolved chromium concentrations were as high as $80 \mathrm{ppb}$, while little or no dissolved chromium was measured under anoxic conditions; for fly ash $B$, no dissolved chromium was detected under oxic or anoxic conditions during the course of the experiment. Total arsenic and chromium concentrations in $6 A$ and $6 B$ include all dissolved arsenic and chromium chemical forms.

\section{Regulations Concerning Coal Ash Disposal and Reuse}

The EPA has recently revised regulations pertaining to the disposal of coal ash in landfills and surface impoundments. Coal ash has been classified as a non-hazardous solid waste, under Subtitle D of the Resource Conservation and Recovery Act (U.S. Environmental Protection Agency, 2015b). The final rule on coal combustion residuals generated by electric utilities (U.S. Environmental Protection Agency, 2015c) requires that coal ash facilities implement: (1) minimum federal regulations for the disposal of coal ash in landfills and surface impoundments, including site location and structural design criteria; (2) routine structural integrity and groundwater assessments; (3) remediation of coal-ash-contaminated groundwater sites; and (4) closure of coal ash disposal facilities with the intention of reducing the risk of failure of coal ash storage facilities and protecting groundwater aquifers. The new regulations do not pertain to beneficial uses of coal ash as defined by the final rule.

\section{Coal Ash Studies Going Forward}

Long-term projected use of coal in electricity generation will require continuing efforts to address the safe storage, disposal, and reuse of large volumes of coal ash. In particular, more research is needed to determine the mobility of environmentally sensitive trace elements during coal ash handling, use, and accidental spills, and ascertain the resulting implications for human health and the environment. Objective, unbiased scientific research such as that performed by the USGS provides information needed for responsible policymaking and to better inform the general public.
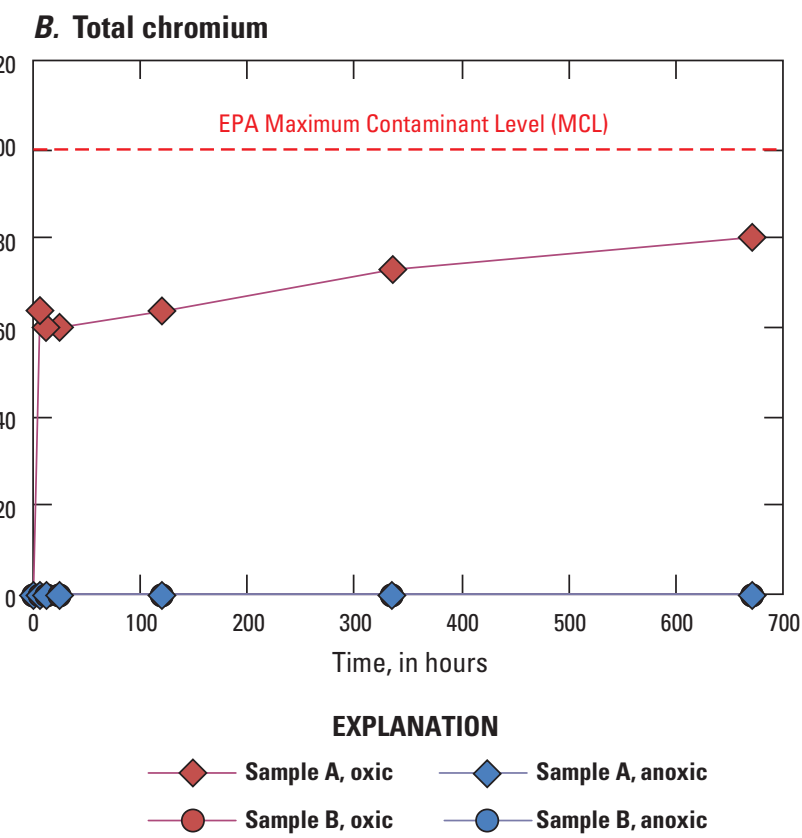


\section{References Cited}

American Coal Ash Association, 2013, 2013 coal combustion product (CCP) production \& use survey report: American Coal Ash Association, accessed March 1, 2015, at http://www.acaa-usa.org/Portals/9/ Files/PDFs/2013ReportFINAL.pdf.

Bragg, L.J., Oman, J.K., Tewalt, S.J., Oman, C.L., Rega, N.H., Washington, P.M., and Finkelman, R.B., 1998, U.S. Geological Survey coal quality (COALQUAL) database, version 2.0: U.S. Geological Survey Open-File Report 97-134, CD-ROM. [Also available at http://energy.er.usgs.gov/products/databases/CoalQual/index.htm.]

Carlson, C.L., and Adriano, D.C., 1993, Environmental impacts of coal combustion residues: Journal of Environmental Quality, v. 22, no. 2, p. 227-247, https://www.agronomy.org/publications/jeq/ abstracts/22/2/JEQ0220020227.

Cheng, C., Taerakul, P., Tu, W., Zand, B., Butalia, T., Wolfe, W., and Walker, H., 2008, Surface runoff from full-scale coal combustion product pavements during accelerated loading: Journal of Environmental Engineering, v. 134, no. 8, p. 591-599, http://ascelibrary.org/doi/abs/10.1061/\%28ASCE\%2907339372\%282008\%29134\%3A8\%28591\%29.

Deonarine, Amrika, Bartov, Gideon, Johnson, T.M., Ruhl, Laura, Vengosh, Avner, and Hsu-Kim, Heileen, 2013, Environmental impacts of the Tennessee Valley Authority Kingston coal ash spill; 2. Effect of coal ash on methylmercury in historically contaminated river sediments: Environmental Science \& Technology, v. 47, no. 4, p. 2100-2108, http://pubs.acs.org/doi/abs/10.1021/es303639d.

Eckley, C.S., and Branfireun, B.A., 2008, Mercury mobilization in urban stormwater runoff: Science of the Total Environment, v. 403, no. 1-3, p. 164-177, http://www.sciencedirect.com/science/article/ pii/S0048969708005469.

Guertin, J., Jacobs, J.A., and Avakian, C.P., eds., 2004, Chromium(VI) handbook: Boca Raton, Fla., CRC Press, 800 p.

Jankowski, J., Ward, C.R., French, D., and Groves, S., 2006, Mobility of trace elements from selected Australian fly ashes and its potential impact on aquatic ecosystems: Fuel, v. 85, no. 2, p. 243-256, http:// www.sciencedirect.com/science/article/pii/S001623610500308X.

Kovler, K., Perevalov, A., Steiner, V., and Metzger, L.A., 2005, Radon exhalation of cementitious materials made with coal fly ash; Part 1-scientific background and testing of the cement and fly ash emanation: Journal of Environmental Radioactivity, v. 82, no. 3, p. 321-334, http://www.sciencedirect.com/science/article/pii/ S0265931X0500055X\#.

Miej, Ruud, 1994, Trace element behavior in coal-fired power plants: Fuel Processing Technology, v. 39, no. 1-3, p. 199-217, http://www. sciencedirect.com/science/article/pii/0378382094901805.

Ruhl, Laura, Vengosh, Avner, Dwyer, G.S., Hsu-Kim, Heileen, Deonarine, Amrika, Bergin, Mike, and Kravchenko, Julia, 2009, Survey of the potential environmental and health impacts in the immediate aftermath of the coal ash spill in Kingston, Tennessee: Environmental Science \& Technology, v. 43, no. 16, p. 6326-6333, http://pubs.acs.org/doi/abs/10.1021/es900714p.

Ruhl, Laura, Vengosh, Avner, Dwyer, G.S., Hsu-Kim, Heileen, and Deonarine, Amrika, 2010, Environmental impacts of the coal ash spill in Kingston, Tennessee; An 18-month survey: Environmental Science \& Technology, v. 44, no. 24, p. 9272-9278, http://pubs.acs.org/doi/abs/10.1021/es1026739.

Ruhl, Laura, Vengosh, Avner, Dwyer, G.S., Hsu-Kim, Heileen, Schwartz, Grace, Romanski, Autumn, and Smith, S.D., 2012, The impact of coal combustion residue effluent on water resources; A North Carolina example: Environmental Science \& Technology, v. 46, no. 21, p. 12226-12233, http://pubs.acs.org/doi/abs/10.1021/ es303263x.
Smedley, P.L., and Kinniburgh, D.G., 2001, A review of the source, behaviour and distribution of arsenic in natural waters: Applied Geochemistry, v. 17, no. 5, p. 517-568, http://www.sciencedirect. com/science/article/pii/S0883292702000185.

U.S. Energy Information Administration, 2013, AEO2014 early release overview: U.S. Energy Information Administration Web page, accessed March 1, 2015, at http://www.eia.gov/forecasts/aeo/er/index.cfm.

U.S. Environmental Protection Agency, 2012a, Region 4; EPA's response to the TVA Kingston Fossil Plant fly ash release-Basic information: U.S. Environmental Protection Agency Web page, accessed February 19, 2015, at http://www.epa.gov/region4/kingston/basic.html.

U.S. Environmental Protection Agency, 2013a, Chromium compounds; Hazard summary: U.S. Environmental Protection Agency Web page, accessed March 6, 2015, at http://www.epa.gov/airtoxics/hlthef/ chromium.html.

U.S. Environmental Protection Agency, 2013b, Basic information about chromium in drinking water: U.S. Environmental Protection Agency Web page, accessed March 1, 2015, at http://water.epa.gov/drink/ contaminants/basicinformation/chromium.cfm.

U.S. Environmental Protection Agency, 2014a, Coal combustion residuals (CCR)-Surface impoundments with high hazard potential ratings: U.S. Environmental Protection Agency Web page, accessed March 1, 2015, at http:/www.epa.gov/wastes/nonhaz/industrial/ special/fossil/ccrs-fs/index.htm.

U.S. Environmental Protection Agency, 2014b, Drinking water contaminants; List of contaminants and their maximum contaminant levels (MCLs): U.S. Environmental Protection Agency Web page, accessed March 1, 2015, at http://water.epa.gov/drink/contaminants/ index.cfm.

U.S. Environmental Protection Agency, 2015a, EPA's response to the Duke Energy coal ash spill in Eden, NC: U.S. Environmental Protection Agency Web page, accessed February 19, 2015, http://www2. epa.gov/dukeenergy-coalash/history-and-response-timeline.

U.S. Environmental Protection Agency, 2015b, Laws \& RegulationsSummary of the Resource Conservation and Recovery Act: U.S. Environmental Protection Agency Web page, accessed March 1, 2015, at http://www2.epa.gov/laws-regulations/summary-resourceconservation-and-recovery-act.

U.S. Environmental Protection Agency, 2015c, 2014 final rule; Disposal of coal combustion residuals from electric utilities: U.S. Environmental Protection Agency Web page, accessed February 19, 2015, at http://www2.epa.gov/coalash/coal-ash-rule.

Zielinski, R.A., Foster, A.L., Meeker, G.P., and Brownfield, I.K., 2007, Mode of occurrence of arsenic in feed coal and its derivative fly ash, Black Warrior Basin, Alabama: Fuel, v. 86, no. 4, p. 560-572, http:/www.sciencedirect.com/science/article/pii/S0016236106003115.

\section{By Amrika Deonarine, Allan Kolker, and Michael Doughten}

\section{For more information, please contact:}

Director, Eastern Energy Resources Science Center

U.S. Geological Survey

12201 Sunrise Valley Drive

Mail Stop 956 National Center

Reston, VA 20192

Phone: 703-648-6401

http://energy.usgs.gov/GeneralInfo/ScienceCenters/Eastern 